\title{
Left ventricular lateral wall pseudoaneurysm presented with decompensated heart failure
}

\author{
Can Ramazan Oncel, ${ }^{1}$ Mustafa Ucar, ${ }^{2}$ Ibrahim Basarici $^{2}$
}

${ }^{1}$ Department of Cardiology, Atatürk State Hospital, Antalya, Turkey

${ }^{2}$ Department of Cardiology, Akdeniz University Faculty of Medicine, Antalya, Turkey

\section{Correspondence to}

Dr Can Ramazan Oncel, r_oncel@hotmail.com

Accepted 23 September 2014

\section{DESCRIPTION}

A 54-year-old woman was admitted to the emergency department with chest pain and orthopnoea for the last 1 month. She had hypertension and type 2 diabetes mellitus. ECG showed ST segment elevation and pathological Q waves in leads I and aVL suggesting previous lateral myocardial infarction (MI). Physical examination revealed blood pressure of 90/ $60 \mathrm{~mm} \mathrm{Hg}$; bibasilar rales and a $(2 / 6)^{\circ}$ late systolic murmur along the left sternal edge due to papillary muscle dysfunction was noted. Antianginal, antithrombotic and heart failure management were instituted immediately. Echocardiographic left ventricular ejection fraction was 35\% and a left ventricular aneurysm formation at the lateral wall with pericardial effusion around the right atrium and lateral free wall was detected. A narrow neck communicating with the aneurysmal cavity, which was lined by fibrous pericardial tissue with no myocardial structure, raised concern for pseudoaneurysm (figures 1 and 2, arrows; video 1). Coronary angiography revealed significant critical trivessel disease. Cardiopulmonary bypass was performed and the true nature of the pseudoaneurysm was confirmed at the time of

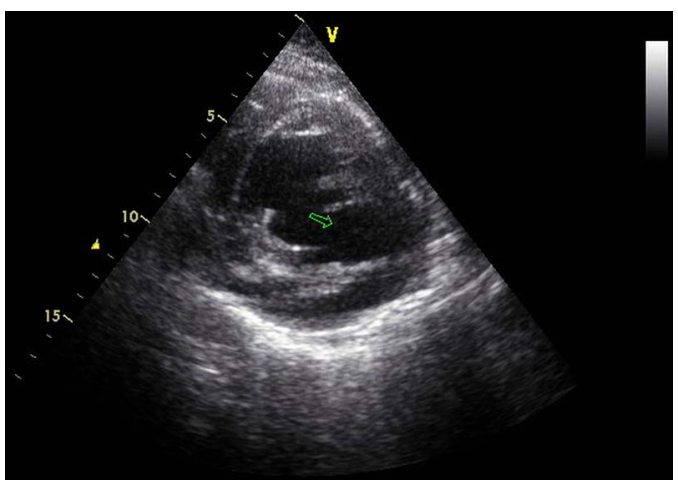

Figure 1 Short axis view demonstrated the pseudoaneurysm (arrow).

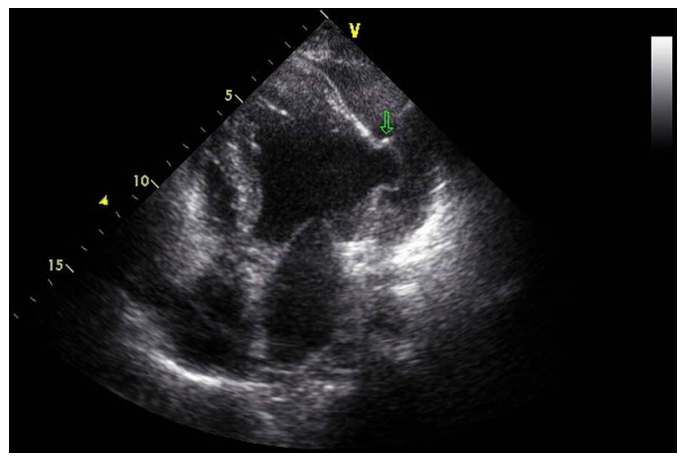

Figure 2 Apical four chamber view demonstrated the pseudoaneurysm (arrow) and pericardial effusion.

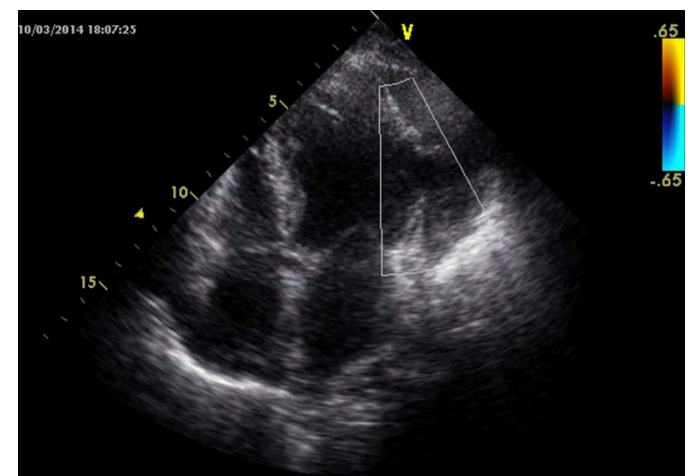

Video 1 Apical four chamber view demonstrated the pseudoaneurysm and pericardial effusion.

surgical inspection as the left ventricular pseudoaneurysm was repaired. The intraoperative course of the patient was satisfactory and later on she was discharged from the hospital without any complication.

Pseudoaneurysms are serious and rare complications of MI. Patients with cardiac pseudoaneurysms usually present with symptoms of chest pain and heart failure. Pseudoaneurysms may contain thrombi and may serve as a thromboembolic source. Pseudoaneurysms associated with symptoms require surgical repair to reduce the risk of rupture. In patients with high risk for surgery, conservative strategy or percutaneous closure may be preferred. ${ }^{1}$

\section{Learning points}

Cardiac pseudoaneurysms are rare but clinically significant lesions.

- Pseudoaneurysms have a neck narrower than the diameter of the aneurysm and are often located in the posterior and lateral wall segment.

- Surgery is recommended in suitable patients as the treatment strategy in order to reduce the risk of fatal rupture.

Contributors $\mathrm{CRO}, \mathrm{MU}$ and IB were responsible for conception and design, revising the manuscript critically for important intellectual content, final approval, literature search, writing, managing the case and as guarantors.

Competing interests None.

Patient consent Obtained.

Provenance and peer review Not commissioned; externally peer reviewed.

\section{REFERENCE}

1 Hulten EA, Blankstein R. Pseudoaneurysms of the heart. Circulation 2012;125:1920-5. 
Copyright 2014 BMJ Publishing Group. All rights reserved. For permission to reuse any of this content visit http://group.bmj.com/group/rights-licensing/permissions.

BMJ Case Report Fellows may re-use this article for personal use and teaching without any further permission.

Become a Fellow of BMJ Case Reports today and you can:

- Submit as many cases as you like

- Enjoy fast sympathetic peer review and rapid publication of accepted articles

- Access all the published articles

- Re-use any of the published material for personal use and teaching without further permission

For information on Institutional Fellowships contact consortiasales@bmjgroup.com

Visit casereports.bmj.com for more articles like this and to become a Fellow 